\title{
Understanding Resources, Competences, and Capabilities in EU Common Security and Defence Policy
}

\author{
August 2015 \\ Robert J. Galavan \\ Edward M Kennedy Institute for Conflict Intervention \& \\ School of Business \\ Maynooth University, Ireland \\ Email: Robert.Galavan@nuim.ie
}

\begin{abstract}
This paper defines key terms for the Improving the Effectiveness of EU Capabilities in Conflict Intervention (IECEU) project. The terms of focal interest are resources, capabilities, competences, together with effectiveness, efficiency, and success. Together they describe the projects interest in improving the capacity of EU missions and operations ${ }^{1}$ (capabilities) to achieve goals (effectiveness) through appropriate use of resources (efficiency) to deliver on EU objectives (success). The paper draws on strategic management literature to provide the theoretical basis and conceptual framework. Having described the interplay of resources, competences, capabilities, and objectives, the paper defines multi-level static, dynamic, and creative capabilities. It then goes on to consider the implications for CSDP and sets established headline civilian and military goals in the framework. There is a brief discussion on the need for comprehensive capabilities to deliver a comprehensive approach. Appendices are provided to indicate possible routes for empirical field work enquiries.
\end{abstract}

Keywords: CSDP, EEAS, EU, conflict intervention, capabilities, resources, competences

Citation:

Galavan, Robert J. 2015. Understanding Resources, Competences, and Capabilities in EU Common Security and Defence Policy (Working Paper).

Note: This paper does not necessarily represent the views of the IECEU Consortium, its members, the EU or its institutions.

1 The European External Action Service (EEAS) used the term mission to denote a civilian activity and operation to denote a military activity. 


\section{Introduction}

Capabilities, competences, and resources are terms that are widely used in business practitioner and academic strategic management literature. The origin of their popular use can be traced to the Resource Based View (RBV) of the firm (Wernerfelt, 1984), which in turn builds on insights from the earlier work of Penrose (1959). Penrose's (1959) work established the fundamental idea that the way people in a firm employ resources, and not just the nature of the resources, effects the success of the firm; "the services yielded by resources are a function of the way in which they are used" (Penrose, 1959: 25). Rubin (1973) provided a detailed economic formalization of Penrose's (1959) idea and made explicit the clear separation between resources and the activities that put those resources to work. While now well recognized as a seminal work, Wernerfelt's (1984) resource-based view of the firm received little attention for many years after its publication. It was Hamel and Prahalad's (1990) publication of their hugely influential practitioner paper on the core-competence of the corporation that brought the ideas to the fore. Barney (1991), building on his own earlier work (Barney, 1986) and that of Dierickx and Cool (1989), rekindled academic interest in RBV with a focus on the source and sustainability of competitive advantage. This work brought together the concept of sustainable competitive advantage based on the nature of the resource, and its non-tradability or path dependence. While the market based concept of sustainable competitive advantage has limited analogues in conflict intervention, the idea that some resources are developed or built within an organization is an important one to which we return towards the conclusion of the paper.

In a separate stream Mahoney and Pandian (1992) focused on resource utilization and management (Mahoney, 1995) as a means to leverage resources. This lead into the work on dynamic capabilities by Teese, Pisano and Shuen (1997) emphasizing the importance of being able to integrate, build and in particular reconfigure competences. In a related stream Winter (1995) reinforces in the importance of routines of interaction, recognizing the importance of collective action and its repeatability. These works set the foundations the explication of multi-level capabilities and the role of organizational assets and collective routines in the production of capabilities.

\section{Defining key terms}

A significant issue for readers and scholars in this field is that there are no agreed "definitions of key concepts, such as resources, competences, core competences, capabilities and dynamic capabilities" (Rugman and Verbeke, 2002 :770). This lacuna is addressed below. Importantly, though, the differences in use of terminology are largely semantic, thus allowing the terms to be defined without being unduly concerned about misrepresenting the underlying concepts. From here on, the term organization is used in place of firm.

Penrose (1959:24) defines an organization as "a collection of productive resources", thus establishing resources as core elements of any organization analysis. Following Penrose (1959), Grant (1991), and Barney (2001) we define resources as tangible and intangible assets, and following Amit and Schoemaker 
(1993) extend the definition to the stocks of tangible and intangible assets that are available to the organization. Following Teece et al. (1997) we define competence as the collective organizational routines used to deploy resources. Finally, following Amit and Schoemaker (1993) we define capabilities as the capacity to deploy a combination of resources through collective organizational routines to a achieve goals.

\begin{tabular}{|l|l|}
\hline Resources & $\begin{array}{l}\text { The stocks of tangible and intangible assets that are } \\
\text { available to the organization }\end{array}$ \\
\hline Competences & $\begin{array}{l}\text { The collective organizational routines used to deploy } \\
\text { resources }\end{array}$ \\
\hline Capabilities & $\begin{array}{l}\text { The capacity to deploy a combination of resources through } \\
\text { collective organizational routines to a achieve goals }\end{array}$ \\
\hline
\end{tabular}

Figure 1: Definition of resources, competence and capabilities

\section{Resources}

Resources in this context are tangible and intangible assets under the effective control of the organization. They are the building blocks of the organization that are combined and deployed to achieve outcomes. The combination of resources, as distinct from their singular use, is a key issue for the management of organizations. Individual assets are components of resource set that provides the potential for outcomes to be achieved.

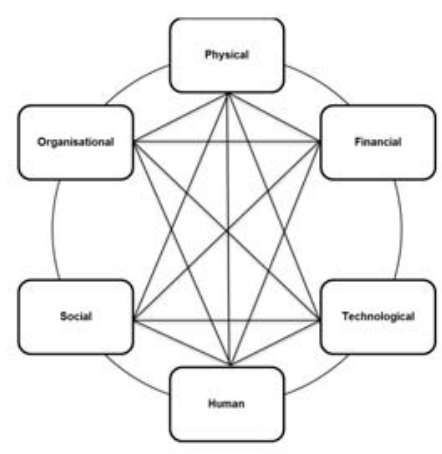

Resources are categorized as

- Physical resources: Buildings, equipment, tools, weapons, etc.

- Financial resources: Cash, budget commitments, or other instruments that are liquid.

- Technological resources: Computers, software, networks, databases, communications systems, satellites, etc.

- Human resources: Physical, intellectual, and emotional.

- Social resources: Relationships, networks, trust, norms, friendships, and reputation.

- Organisational resources: Information, systems (formal and informal), procedures, structures, management know-how, culture, organizational relationships (e.g. alliances), etc.

Resources are often closely related with specific activities that can reinforce them. For example fitness is a human capital asset and exercise is a process activity.

\section{Competences}

Resources in of themselves do not achieve anything. They are a stock of assets that have potential to be used to achieve outcomes. Objectives are addressed by putting the resources into action. This action, in an organization context, will always involve interaction with others, and this interaction is a defining 
characteristic of an organizational competence. Individual action, is by definition, not an organizational competence. Certainly there will be many individual actions involved in achieving organizational outcomes, but the achievement of the outcomes is not a result of adding individual actions, it is the outcomes of complex interactions between individuals. Competences are always based in collective interactions.

Interactions are events and difficult to study, particularly in cross sectional work. This is not however a significant issue for those studying organizations. In such work the interest is not typically in events, but in patterns of events. These patterns emerge through the application of tacitly or explicitly understood processes which in the collective become routines (in contrast to a habit at an individual level). Because they are social activities the routines are not deterministic in the mechanical sense. They are "generative systems that produce recognizable, repetitive patterns of interdependent actions carried out by multiple actors" (Pentland and Feldman, 2008 :235). These recognizable and repetitive patterns are much more amenable to study.

Competences have ostensive or structural as well as performative (FelinFossHeimeriks et al., 2012) or transformational characteristic to them. They deploy resources or more commonly a set of resources to cause a change. They are activities that the organization performs with some proficiency, and importantly, is repeatable. Without repeatability the organization cannot be said to have the competence. An organization may witness a competence in a once off event, but to have it at its disposal it must have the capacity to repeat it. This capacity is embedded in a tacit or explicit organizational routine.

An important aspect of a routine is that it is contextualized. Routines do not exist in manuals, process diagrams, individual minds, or computer systems. They are social level constructs. In market organizations they form the basis of some competitive advantage because they are difficult to imitate. They are not easily transferrable from one organization to another. While this is a distinct benefit to market organization, the difficult transferring competence to new missions or operations (assuming it exists elsewhere) as they become established, is a significant issue.

\section{Capabilities}

Capabilities are the capacity to deploy a combination of resources through collective organizational routines to a achieve goals. Following Winter (1995:991) an organizational capability is a high level routine or set of routines, that together with resource stocks provide management with a range of decision options to produce particular and desired high level outcomes. Capabilities are therefore fundamental building blocks of strategy implementation. 


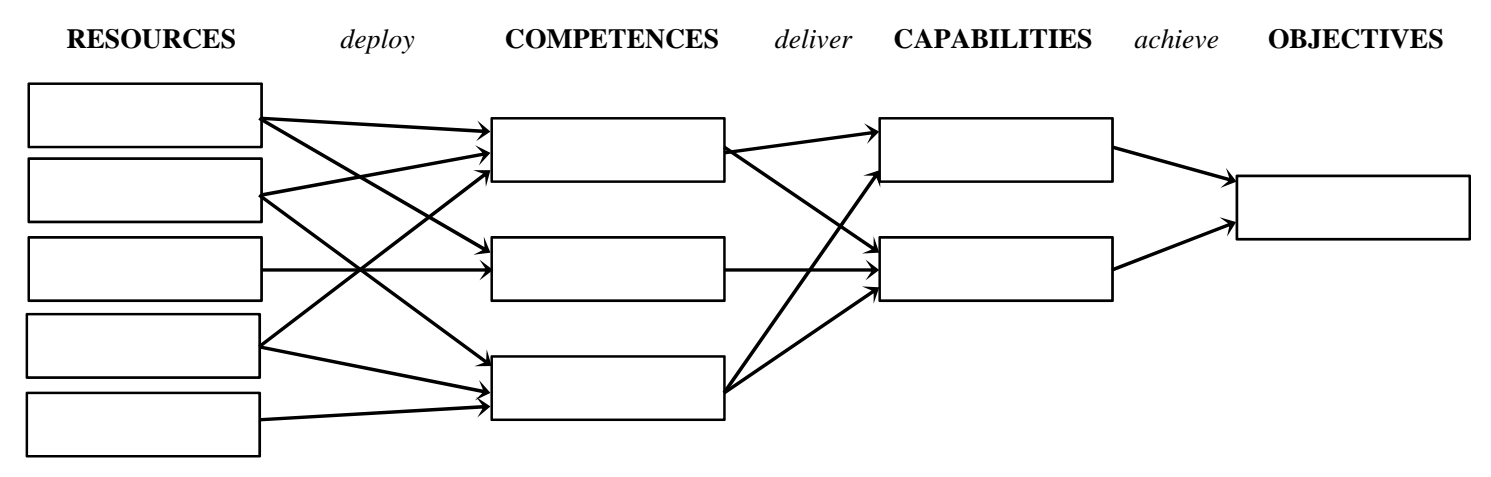

Figure 2 : Building blocks of strategy implementation

Capabilities shaped by collective routines also have properties established in a hierarchy. These properties define the system (routines and resources) potential to reorganize its self. Highly codified routines using established and known resources have no such self-organization capacity. These static capabilities allow organizations to operate in a well-established status quo; Winter (2003) terms these as zero level capabilities. Grant (1991:120) notes that these static capabilities can be identified "using a standard functional classification of the firms activities".

At the next level, in order to change an organisation's capabilities, the static capabilities need to be modified. If they are to be modified from within the organization, then the organization must possess dynamic capabilities, termed first order capabilities by Winter (2003). Dynamic capabilities allow organizations to sense changing requirements, select new capability configurations and transform their resource sets and routines (Teece, 2007). Dynamic capabilities consist of knowledge accumulation and transfer routines, experimentation and continuous improvement. Dynamic routines bring learning patterns that embrace diversity, multiple paths, and combinatory effects (LeiHitt and Bettis, 1996). The impact of dynamic capabilities manifest in improved, extended, and newly developed static capabilities.

A key characteristic of dynamic capabilities is learning from experience, using feedback from implementation of static capabilities to improve. Winter (2003) proposes that there is yet a higher level capabilities, acknowledging the limits of learning from experience alone. Collis (1994:145) describes these as "metaphysical strategic insights" that enables organizations to develop "novel strategies". These higher level capabilities bring creativity into the discussion (Pandza and Thorpe, 2009). This creative capability to change the organizations dynamic capabilities is the ability to learn how to learn. Ambrosini et al. (2009) term this a regenerative capability and organizations require these capabilities when the environment is discontinuous or non-linear (D'aveni, 1994). Creative capabilities allow organizations to move beyond learning from their experience and bring imagination into play the imagination to conceive of configurations and approaches not yet seen. 
“You see things; and you say, 'Why?' But I dream things that never were; and I say, 'Why not?”

The Serpent in Back to Methuselah by George Bernard Shaw

It is at this creative level that the capabilities concept approaches its limits. A fundamental aspect of an organizations capabilities are the routines that underpin them. The more the creative component becomes important, particularly the ability for non-linear jumps, the more difficult it is to identify the role of repeatable routines. That is not to say that there is no role for routine in creativity; creative thinking can benefit from elements of routine (Haner, 2005) but may in not in itself be routinized. How dynamic an organizations dynamic organizational capabilities can be was addressed by Schreyögg and Kliesch-Eberl (2007), who concluded that higher order capabilities need not eschew routinisation, but require dual processing capabilities. Creative capabilities generate options, and within that option set organizations can choose across the range of total-change to no change. In practice organizations will choose combinations across that range and so creative capabilities are not a linear route to transformation, but a more sophisticated dual processing approach of learning to change and learning to stay (Schreyögg and Noss, 2000).

\begin{tabular}{|c|c|c|c|}
\hline Level & Description & Focus & Other literature \\
\hline Static & $\begin{array}{l}\text { Capabilities based in } \\
\text { established routines } \\
\text { and resources }\end{array}$ & $\begin{array}{l}\text { Efficiency in } \\
\text { delivering outputs }\end{array}$ & $\begin{array}{l}\text { Static (Collis, 1994); } \\
\text { First order (Danneels, } \\
\text { 2002); } \\
\text { Zero level (Winter, 2003); } \\
\text { Substantive } \\
\text { (ZahraSapienza and } \\
\text { Davidsson, 2006); } \\
\text { Operational (Easterby- } \\
\text { Smith and Prieto, 2008) } \\
\text { Resource base (Ambrosini } \\
\text { et al., 2009) }\end{array}$ \\
\hline Dynamic & $\begin{array}{l}\text { Capabilities to sense } \\
\text { need and opportunity, } \\
\text { select from options, } \\
\text { and (re)configure } \\
\text { static resources and } \\
\text { routines }\end{array}$ & $\begin{array}{l}\text { Effectiveness in } \\
\text { achieving objectives }\end{array}$ & $\begin{array}{l}\text { Dynamic (Collis, 1994); } \\
\text { Second order (Danneels, } \\
2002) ; \\
\text { First order (Winter, 2003); } \\
\text { Dynamic (Zahra et al., } \\
\text { 2006); } \\
\text { Dynamic (Easterby-Smith } \\
\text { and Prieto, 2008); } \\
\text { Incremental/renewing } \\
\text { dynamic (Ambrosini et al., } \\
\text { 2009); } \\
\text { First-order (Schilke, 2014) }\end{array}$ \\
\hline Creative & $\begin{array}{l}\text { Capabilities to } \\
\text { creatively engage } \\
\text { with exogenous } \\
\text { sources, dual process } \\
\text { change or stay } \\
\text { decisions, and } \\
\text { reconfigure dynamic } \\
\text { resources and } \\
\text { routines }\end{array}$ & $\begin{array}{l}\text { Effectiveness of } \\
\text { objectives in } \\
\text { achieving highest } \\
\text { level goals }\end{array}$ & $\begin{array}{l}\text { Creative (Collis, 1994); } \\
\text { Higher order (Winter, } \\
\text { 2003); } \\
\text { Learning (Easterby-Smith } \\
\text { and Prieto, 2008); } \\
\text { Regenerative dynamic } \\
\text { (Ambrosini et al., 2009); } \\
\text { Strong dynamic (Teece, } \\
\text { 2014); } \\
\text { Second-order dynamic } \\
\text { (Schilke, 2014) }\end{array}$ \\
\hline
\end{tabular}

Table 1: Capability Levels 


\section{Setting the capability levels in context}

In line with the ambition to fulfil the EU's potential in promoting and preserving peace and stability, the EU will actively and effectively use the full spectrum of instruments at its disposal for crisis management and conflict prevention. The EU will act through CSDP missions and operations to add value, on the basis of identified needs, with clear objectives and exit strategies to deliver and sustain results.

(Council of the European Union, 2011)

Levels of capabilities will be broadly, but not exclusively, aligned with political, strategic and operational structures within CSDP (see Appendix 1).

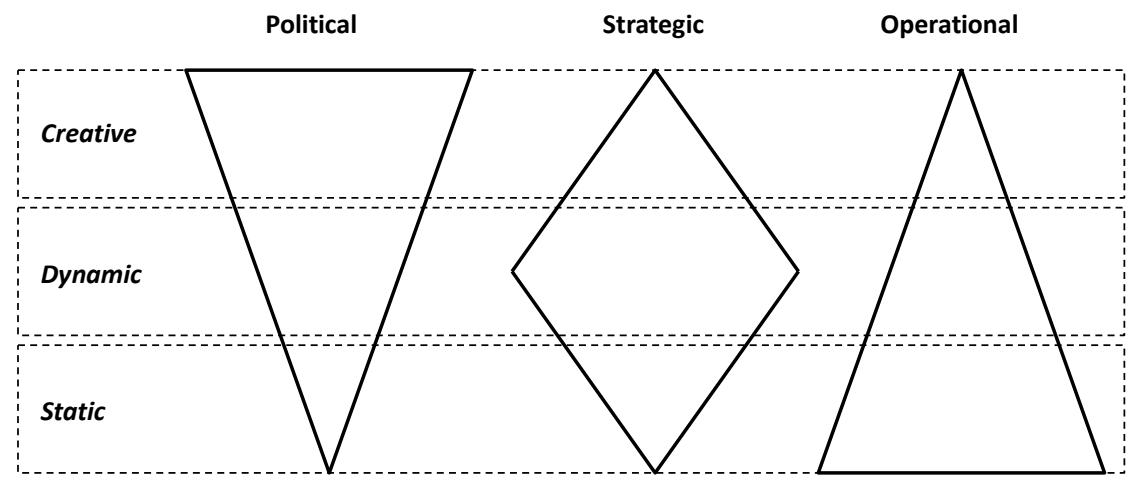

Figure 3: CSDP institutions and alignment with capability levels

While each level is conceptually distinct, institutions will not demonstrate formal boundaries across them and all institutions will practice, to some extent, at each level. Where objectives are appropriately set they act as self-regulating guidance systems. For example EUSC will utilize its limited resource set to address, primarily, operational excellence in satellite imaging, rather than seek to shape creative modes of conflict intervention. The PSC will consider social, democratic, and other exogenous forces on approaches to conflict intervention, and will likely have little operational knowledge of cyber counter measures to corruption in conflict zones. Once institutions are held accountable for delivery of appropriate objectives and have the freedom to enact dynamic capabilities, they will shape their capability profile. Those responsible for operational delivery (and in particular functions within institutions) will learn what works in their context, given localized demands, and the available resource set. Those operating at the political and diplomatic level soon recognize that heavily codified routines will not solve complex issues such as societal crises, and military commanders easily recognize that creative approaches to maintenance of complicated equipment stocks will not keep it in top condition. Each institution must have the appropriate dynamic capability to sense, select, and implement the appropriate capability set. 
The challenge for crisis intervention at the EU level is that all of the levels must work together to achieve successful societal outcomes. It is beyond the scope of this paper deconstruct the issue, but a key challenge in this regard is the interaction of institutional cultures. At the extremes one sees this in a military desire for explicit rules of engagement and a political/diplomatic desire to keep options open. There is nothing wrong with these different approaches, in fact they are essential. A military with the capacity for extreme force should not have the independent creative freedom to decide how that force should be applied. Soldiers with weapons should have rules, and political leaders should be encouraged to imagine better ways to deal with societal challenges.

\section{CSDP Capabilities}

The EU is unique and does not comply with the strict design of a federation or a confederation. It has been described as a unique brand of constitutional federalism (Weiler, 2003). Political and legal implications aside, this creates a perpetual challenge for actions taken by the EU. In the EU parlance many resources and capabilities are defined as being in the 'competence'2 of the nation state. The (consolidated version of the) Treaty on the Functioning of the European Union (TFEU) (European Union, 2012) separates these 'competences' into 4 distinct categories, exclusive (Article 3), shared (Article 4), support (Article6), and arrangement (Article 5), each moving progressively from central to local and informed by the well established EU subsidiarity principle.

The TFEU also establishes a 'competence' for the EU in relation to CSDP, within the context of the Common Foreign and Security Policy (CFSP); although it is much less developed 'competence' framework than in other areas. The Lisbon Treaty (which came into force in 2009) continued the development of this 'competence' through the establishment of an EU diplomatic corps, the European External Action Service (EEAS) which supports the post of EU High Representative for Foreign Affairs \& Security Policy. The holder of the post is also ex-officio Vice President of the European Commission, a participant at meetings of the European Council, President of the Foreign Affairs Council, President of the European Defence Agency, and Chairperson of the Board of the Institute for Security Studies, and coordinates the work of other EU Special Representatives.

In relation to CSDP missions and operations the EEAS and its institutions have the competence to coordinate actions and facilitate cooperation. Decisions in relation to CSDP actions are fundamentally an intergovernmental responsibility through the Council of the EU which has significant autonomy to set policy and approve activities. When the Council of the EU decides on CSDP policy it presents a single EU voice to which the EEAS responds, but getting agreement across member states is often a difficult and time consuming process. The operational implementation of agreed actions then depends on civil and military assets provided largely by individual member states through a force generation process in the

2 The term competence used in this way by the EU is not an organizational competences as used in this paper. 
military stream and more ad hoc mission staffing procedures through national authorities in the civilian stream. It is in this unique context that CSDP capabilities must be viewed.

\section{Resources}

With the exception of centralised coordinating capabilities of CSDP, capabilities exist in and under the control of the member states. This creates a challenge for planners and strategists to know what resources exist, and then to gain an understanding of their quality, interoperability, and availability (effected both by political will and operational capacity). This is compounded by the fact that the EU is heterogeneous, somewhat geographically, but more obviously culturally, with differing historical relationships, levels of trust, organizational approaches, perspectives on hierarchy, financial strength, governance styles and abilities, relationships with neighbours and beyond.

Key questions to address in this context are:

- What member state resource set is notionally available to CSDP?

\section{Capabilities}

The Council of the European Union (2008) has established headline goals for civilian missions and military operations. For civilian missions the following capability goals are identified:

Static capability (support functions) - development

- Develop the administrative, financial, logistical and human resources aspects of the mission support function, including by seeking to optimise the synergy ${ }^{3}$ between civilian and military assets

Static and dynamic capability - replication

- Strengthen the EU's capability to plan and deploy several missions at the same time, in particular in rapid-response situations

Dynamic capability - development

- Continue to develop suitable management tools for efficiently mobilising capabilities needed for civilian missions

- Improve training for personnel likely to be deployed on missions, and continuing to strengthen civilian response teams

- Develop national strategies to facilitate the deployment of mission personnel and encourage exchange of good practices between Member States

- Introduce a proper feedback system for ESDP civilian missions

${ }^{3}$ Synergy could also refer to dynamic capabilities. In this case it is assessed to be a cost saving measure in the static capability of functional areas. 
Creative capability- development

- Strengthen the coherence and synergies between ESDP missions and other European Union instruments [accounts for exogenous information]

The civilian goals contrast somewhat with the military goals which are more heavily resource and static capability oriented. It is however clear that the development of dynamic capabilities is an emerging priority. Creative capabilities do not feature in the military goals. At one level this is unsurprising given the nature of military in the EU and their response to political tasking rather than leadership on issues. At another level it is surprising that novel approaches do not feature, given the evolving nature of warfare and the changing sources of threats. The military capability goals include:

\section{Resources}

- Modernisation of helicopters and training of crews

- Preparation of a blueprint for a future transport helicopter

- Establishment of a European air transport fleet

- A multinational unit of A400M aircraft

- Concept development of a European airbase for a European force

- European Carrier Group interoperability initiative involving an aircraft carrier, carrier air groups, and escort vessels ${ }^{4}$

- Cosmo, Skymed, and Helious 2 satellite images to EUSC

- Observation satellites (MUSIS)

- EDA future surveillance UAV project

Static capability - development

- Establishment of European airlift command

- Information gathering and space based intelligence

- Space surveillance

- Protection of forces assets and efficiency in operation

- EDA programme for mine clearance

- Networking of maritime surveillance systems

- Development if approach for mobilisation of military assets for evacuating European nationals

- Creation of European teams of experts that can be deployed to back up SSR

Dynamic capability - development

- EU special operations concept, including special forces cooperation

${ }^{4}$ The interoperability aspect of the capability could be dynamic in nature, but the emphasis is on asset acquisition. 
- Strengthen interoperability

- Development of exchanges of young officers

- Improved functioning of the ESDC

- Establish joint capabilities by sharing national capabilities

- Organise and use capabilities on a collective, sustainable basis by pooling capabilities and devolving the management of assets to a multinational cooperative structure

- For niche capabilities, or those which are rare or costly, specialisation, on a voluntary basis, which would require the strengthening of forms of mutual interdependence between European States

- Procurement of collective, multinational critical capabilities among some European countries

\section{Discussion}

Human systems, societies, particularly societies in conflict, create evolving complex challenges. In situations of substantial conflict, there is no static capability (set of resources and competences) that can be borrowed from elsewhere and applied. The desired outcomes are multifaceted and temporal, and the challenges are highly contextualised. The EU recognises that the desired outcomes are not isolated components, but rather part of a comprehensive system, and so require a comprehensive approach. A comprehensive approach, in turn, requires comprehensive capabilities.

In the broad sense, CSDP strategic institutions (including established missions and operations) have responsibility for organizational competence in analyzing situations (sensing), defining strategy (selecting from options), and mission/operation implementation (configuring options). The former is constrained by the nature of the EU political system, and the latter by the resource set made available by the member states (and their contextual embeddedness). Efforts towards pooling and sharing, staff exchange, and other modes of cooperative behaviour are means of alleviating the issues associated with locally embedded capabilities that need to be brought to bear in non-local contexts.

The question of whether the EU needs to act as the EU in CSDP is a politically charged issue. Even so, it is a question that must be properly addressed. To progress the answer, some variables can be taken out of the political orbit, and analysed in terms of the appropriateness of capabilities in respect of their objectives. If there are challenges and threats that can be addressed by individual member states, then there may be little value in other EU states developing those capabilities. The principles of subsidiarity and proportionality suggest supporting the capability in the local. If the threat requires capabilities established in more than one member state (and beyond) and across institutional forms, then coordination capabilities are required. If the threats and challenges are evolving, then the capabilities must evolve to meet them. This requires shared dynamic capabilities to sense, select options, and implement reconfigurations. Sharing at this level requires more than physical transfer; it involves shared culture, trust, and understanding. If the situation requires complex novel responses to previously unseen threats at 
a large scale, then the EU needs shared, creative, and dual processing capabilities to imagine new futures and select appropriately. These are not political needs, these are necessities driven by our environment.

If the $\mathrm{EU}$ is to act as the $\mathrm{EU}$ in the face of complex threats, then there must be comprehensive $\mathrm{EU}$ capabilities at static, dynamic, and creative levels. These shared capabilities will not emerge from the addition of strictly nationalised resources and capabilities. The development of capabilities requires competence development in the form of established collective routines. These routines are path dependent and cannot be acquired at the moment they are needed. This holds implications for the central CSDP institutions and agencies, and for the formation of effective missions and operations. In this context, preparation for tomorrow began yesterday. 


\section{Appendix 1: CSDP agency and institution orientations}

The CSDP operates within the political context of the European Union. The EU has established a set of institutions, structures and agencies to address its goals in relation to CSDP. These are

\section{Political}

- Political and Security Committee (PSC)

- European Union Military Committee (EUMC)

- Committee for Civilian aspects of Crisis Management (CIVCOM)

- Politico- Military Group (PMG)

\section{Strategic}

- Crisis Management and Planning Directorate (CMPD)

- European Union Military Staff (EUMS)

- Civilian Planning and Conduct Capability (CPCC)

- European Union Institute for Security Studies (EUISS)

- European Defence Agency (EDA) (also has an operational role)

\section{Operational}

- EU Missions and Operations

- EU Operations Centre (EU OPCEN)

- European Union Satellite Centre (EUSC)

- European Security and Defence College (ESDC) 


\section{Appendix 2: Questions at each competency level}

\section{Static}

- Do CSDP missions/ and operations have the capability to deliver defined functional outputs?

- To what extent has CSDP mission and operations capability been effected by the availability of basic resources (e.g. staff, technology, equipment, procedure manuals, management expertise, social ties, etc.)?

- To what extent has CSDP mission and operations efficiency of implementation been influenced by the contextually embeddedness of competences (resources and collective routines) in the member state(s)?

- What has/can be done to aid the transfer of (functional) organizational competences from member states to CSDP activities? (Consider civil-military differences.)

\section{Dynamic}

- Do CSDP missions and operations have the capability to be effective in the delivery of established mission and operations objectives?

- Have the established EU CSDP institutions and agencies the capability to reliably and repeatedly sense changing needs, select appropriate options, and reconfigure (including the establishment of new) resources and routines? If so how is this achieved?

- Have EU CSDP missions and operations the capability to sense changing needs, select appropriate options, and reconfigure (including the establishment of new) resources and routines? If so how is this achieved?

- Have EU missions and operations the capability to operate a 'comprehensive approach'?

- What have been the major barriers to improvement?

- What have been the major enablers of improvement?

\section{Creative}

- Does the CSDP have the capability to establish the effectiveness of its objectives in achieving the highest level societal goals?

- Have the CSDP institutions the capability to access and interrogate exogenous knowledge?

- Have CSDP agencies and institutions the capability to reflect on, conceive of, and influence system wide changes that can produce novel approaches to conflict intervention where established approaches are sub optimal?

- What have been the major barriers to the development of appropriate novel approaches?

- What have been the major enablers in the development of appropriate novel approaches? 


\section{Appendix 3: Field work oriented questions for missions/operations}

- What are the mission/operation prime objectives? (objectives)

- What does the mission/operation do? What are the most important activities? (activities, services, outputs)

- What are the key things that makes those activities possible? (competences)

- What are the most important resources for those activities? (physical, financial, human, technological, social, organizational)

- What barriers do you encounter? (This may be the absence of competences and resources or the presence of the wrong competences and resources)

- Could you describe some breakthroughs that you have had?

o What activities made them possible

o What were the key assets

o What were the barriers you encountered?

- $\quad$ Static capabilities

o Known configurations of resources and competences

o The capabilities to achieve well specified outcomes within understood contexts

- Dynamic capabilities

o reconfiguring existing resources and competences

o The ability to learn, adapt and improve capabilities over time and in the face of changing circumstances

- $\quad$ Creative (meta) capabilities

o Create innovative solutions to higher order challenges

o The ability to learn how to learn, reimagine capabilities and reframe challenges 


\section{References}

Ambrosini, V., Bowman, C. \& Collier, N. 2009. Dynamic Capabilities: An Exploration of How Firms Renew Their Resource Base. British Journal of Management, 20, S9-S24.

Amit, R. \& Schoemaker, P. J. H. 1993. Strategic Assets and Organizational Rent. Strategic Management Journal, 14, 33-46.

Barney, J. B. 1986. Strategic Factor Markets: Expectations, Luck, and Business Strategy. Management Science, 32, 1231-1241.

Barney, J. B. 1991. Firm Resources and Sustained Competitive Advantage. Journal of Management, 17, $99-120$.

Barney, J. B. 2001. Resource-Based Theories of Competitive Advantage: A Ten-Year Retrospective on the ResourceBased View. Journal of Management, 27, 643.

Collis, D. J. 1994. Research Note: How Valuable Are Organizational Capabilities? Strategic Management Journal, 15, 143-152.

Council of the European Union. 2008. Declaration on Strengthening Capabilities,

Council of the European Union. 2011. Council Conclusion on Common Security and Defence Policy, 3130th Foreign Affairs Council Meeting

D'aveni, R. A. 1994. Hypercompetition.

Danneels, E. 2002. The Dynamics of Product Innovation and Firm Competences. Strategic Management Journal, 23, 1095-1121.

Dierickx, I. \& Cool, K. 1989. Asset Stock Accumulation and Sustainability of Competitive Advantage. Management Science, 35, 1504-1511.

Easterby-Smith, M. \& Prieto, I. M. 2008. Dynamic Capabilities and Knowledge Management: An Integrative Role for Learning? British Journal of Management, 19, 235-249.

European Union. 2012. Consolidated Version of the Treaty on the Functioning of the European Union, OJ C 326,

Felin, T., Foss, N. J., Heimeriks, K. H. \& Madsen, T. L. 2012. Microfoundations of Routines and Capabilities: Individuals, Processes, and Structure. Journal of Management Studies, 49, 1351-1374.

Grant, R. M. 1991. The Resource-Based Theory of Competitive Advantage: Implications for Strategy Formulation. California Management Review, 114-135.

Hamel, G. \& Prahalad, C. K. 1990. The Core Competence of the Corporation. Harvard Business Review, 79-91.

Haner, U.-E. 2005. Spaces for Creativity and Innovation in Two Established Organizations. Creativity and Innovation Management, 14, 288-298.

Lei, D., Hitt, M. A. \& Bettis, R. 1996. Dynamic Core Competences through Meta-Learning and Strategic Context. Journal of Management, 22, 249-269.

Mahoney, J. T. 1995. The Management of Resources and the Resource of Management. Journal of Business Research, $33,90-101$.

Mahoney, J. T. \& Pandian, R. J. 1992. The Resource-Based View within the Conversation of Strategic Management. Strategic Management Journal, 13, 363-380.

Pandza, K. \& Thorpe, R. 2009. Creative Search and Strategic Sense-Making: Missing Dimensions in the Concept of Dynamic Capabilities. British Journal of Management, 20, S118-S131. 
Penrose, E. T. 1959. The Theory of the Growth of the Firm, New York, John wiley.

Pentland, B. T. \& Feldman, M. S. 2008. Designing Routines: On the Folly of Designing Artifacts, While Hoping for Patterns of Action. Information \& Organization, 18, 235-250.

Rubin, P. H. 1973. The Expansion of Firms. Journal of Political Economy, 81, 936-949.

Rugman, A. M. \& Verbeke, A. 2002. Edith Penrose's Contribution to the Resource-Based View of Strategic Management. Strategic Management Journal, 23, 769-780.

Schilke, 0. 0. a. E. 2014. Second-Order Dynamic Capabilities: How Do They Matter? Academy of Management Perspectives, 28, 368-380.

Schreyögg, G. \& Kliesch-Eberl, M. 2007. How Dynamic Can Organizational Capabilities Be? Towards a Dual-Process Model of Capability Dynamization. Strategic Management Journal, 28, 913-933.

Schreyögg, G. \& Noss, C. 2000. Reframing Change in Organizations: The Equilibrium Logic and Beyond. Academy of Management Proceedings \& Membership Directory, B1-B6.

Teece, D. J. 2007. Explicating Dynamic Capabilities: The Nature and Microfoundations of (Sustainable) Enterprise Performance. Strategic Management Journal, 28, 1319-1350.

Teece, D. J. 2014. The Foundations of Enterprise Performance: Dynamic and Ordinary Capabilities in an (Economic) Theory of Firms. Academy of Management Perspectives, 28, 328-352.

Teece, D. J., Pisano, G. \& Shuen, A. 1997. Dynamic Capabilities and Strategic Management. Strategic Management Journal, 18, 509-533.

Weiler, J. H. H. 2003. Federalism without Constitutionalism: Europes' Sonderweg. The Federal Vision: Legitimacy and Levels of Governance in the United States and the European Union. Oxford: Oxford University Press.

Wernerfelt, B. 1984. A Resource-Based View of the Firm. Strategic Management Journal, 5, 171-180.

Winter, S. G. 1995. Four Rs of Profitability: Rents, Resources, Routines, and Replication. In: Montgomery, C. A. (ed.) Resource-Based and Evolutionary Theories of the Firm: Towards a Synthesis. Dordrecht and Boston:

Kluwer Academic.

Winter, S. G. 2003. Understanding Dynamic Capabilities. Strategic Management Journal, 24, 991-995.

Zahra, S. A., Sapienza, H. J. \& Davidsson, P. 2006. Entrepreneurship and Dynamic Capabilities: A Review, Model and Research Agenda. Journal of Management Studies, 43, 917-955. 